\title{
THE COMPARISON OF TECHNICAL EFFICIENCY ON CATTLE BREEDING BUSINESS BETWEEN SHARE-BEEF CATTLE MODEL AND FARMER-OWN BEEF CATTLE MODEL AT MUARO JAMBI REGENCY, JAMBI PROVINCE
}

\section{PERBANDINGAN EFISIENSI TEKNIS USAHA PEMBIBITAN SAPI POTONG POLA USAHA GADUHAN DAN POLA USAHA MANDIRI DI KAB MUARO JAMBI, JAMBI PROVINCE}

\author{
Bagus Pramusintho ${ }^{1 *}$, Slamet Hartono ${ }^{2}$, Any Suryantini ${ }^{2}$, dan Dwidjono Hadi Darwanto ${ }^{1}$ \\ ${ }^{1}$ Department of Animal Production,Faculty of Animal Husbandry, Jambi University, Jambi, 36361 \\ ${ }^{2}$ Department of Agricultural Socio Economics, Faculty of Agriculture, Gadjah Mada University, \\ Yogyakarta, 55281
}

Submitted: 30 January 2017, Accepted: 10 October 2017

\begin{abstract}
The lack of capital for investment and limited access for small beef cattle farming to obtain credit from financial institution have contributed to the occurrence of share-beef cattle in rural areas. Through share-beef cattle pattern, the farmers (tenant) can rent livestock from other parties (individual nor government) within a share-beef cattle contract agreement. The purposes of this study were to determine the technical efficiency and the factors which influence the inefficiency from 108 small beef cattlebreeding which consists of 59 farming operated by owner and 49 operated by tenant. The unit samples were selected by snowball sampling method and analysed by Stochastic Frontier Production. Our study showed that the average technical efficiency of beef cattle breeding operated by owner was at 0.73 , otherwise operated by tenant was at 0.790 . The inefficiency of beef cattle breeding operated by owner has negatively corresponded to the number of cows, the farmer age, the age of cow and the application of artificial insemination (IA), but positively corresponded to allocation of family labour and level of farmer education. The inefficiency of beef cattle breeding operated by a tenant has negatively corresponded to the application of artificial insemination (Al). Specific conclusion of the study was the technical efficiency level of small beef cattle breeding was not only affected by the ownership of beef cattle but also by the pattern of share-beef cattle. The share-beef cattle based on share income(50:50) may improve the value of technical efficiency compared to share-beef cattle based on share in-kind (share-beef cattle revolving cow or share-beef cattle revolving calf).
\end{abstract}

(Keywords: Beef cattle breeding, Share-beef cattle, Stochastic Frontier Analysis, Technical efficiency)

\section{INTISARI}

Terbatasnya modal investasi dan akses peternak skala kecil mendapatkan kredit produksi dari lembaga keuangan merupakan salah satu faktor pendorong berkembangnya model gaduhan ternak sapi di wilayah pedesaan. Melalui model gaduhan ternak sapi peternak dapat meningkatkan jumlah pemeliharaan ternak dengan cara mengaduh ternak dari perorangan maupun pemerintah. Ditinjau dari teori tradisional"share-tenancy" pada kasus lahan pertanian menyebabkan inefisiensi pengalokasian sumber daya. Tujuan penelitian ini untuk mengetahui tingkat efisiensi teknis produksi dan faktor-faktor yang mempengaruhi inefisiensi dari 108 usaha ternak sapi potong pola pengembangbiakkan (induk anak) yang terdiri dari 59 usaha ternak yang dikelola oleh peternak pemilik dan 49 dikelola peternak penggaduh. Unit sampel dari penelitian ini adalah usaha pembibitan ternak, dengan metode penentuan sampel metode snowball sampling. Metode analisis yang digunakan Stochastic Frontier Production Analysis. Hasil dari penelitian menunjukkan bahwa rata-rata tingkat efisiensi teknis usaha ternak yang dikelola peternak pemilik sebesar 0,732; dan yang dikelola oleh peternak pengaduh sebesar 0,790. Inefisiensi usaha ternak yang dikelola oleh peternak-pemilik berhubungan negatif dengan: jumlah sapi induk, usia peternak, umur sapi induk, penggunaan Inseminasi Buatan (IB); dan secara positif dipengaruhi oleh: penggunaan tenaga kerja keluarga dan tingkat pendidikan peternak. Inefisiensi teknis peternakan sapi yang dikelola oleh penggaduh berhubungan negatif dengan penggunaan Inseminasi Buatan (IB). Kesimpulan spesifik dari penelitian ini, tingkat efisiensi teknis dari usaha ternak sapi induk anak tidak hanya dipengaruhi oleh

* Korespondensi (corresponding author):

Telp. +62 82322219696

E-mail: bpramusintho@gmail.com 
status kepemilikan ternak namun juga dipengaruhi oleh pola gaduhan ternak sapi potong. Pola gaduhan ternak sapi potong berdasarkan bagi hasil pendapatan (50:50), dapat meningkatkan efisiensi teknis dibandingkan pola gaduhan bagi hasil inkind (gaduhan guliran induk maupun gaduhan guliran pedet).

(Kata kunci: Analisis efisiensi stokhastik, Bagi hasil ternak, Efisiensi teknis, Sistem pembibitan sapi)

\section{Introduction}

The government of Indonesia has announced a program to reach beef cattle self-sufficiency in 2014 so that the $90 \%$ of national demand could be supplied from domestic production. However, until the end 2014 , it could not be realised. The proportion of import beef and cattle feeders to fulfil the national demand was still about $18 \%$ and unfortunately, the beef cattle population in 2013 declined from 16.49 million in 2012 to 13.27 million (BPS, 2014). This situation required an evaluation of stakeholders to examine the strategic policies related to improving the domestic beef cattle production and population.

One of the many problems to increasing domestic beef cattle production in Indonesia was caused by the majority of beef cattle producers (90\%) are small-scale farming which operated in resource constraints especially capital-constraint (Sodiq and Budiono, 2012). The existence of limited resources, causing the farmers can't use the resources as needed, resulting in low productivity and lower growth (Widiati, 2012), and drive into an inefficient business (Hadi and Ilham, 2002). Related to capital constraints, (Simatupang et al., 1994) argue that the lack of access to institutional credit in beef cattle sub-sector had contributed to the emergence of share-beef cattle patterns in rural areas. Similar to the circumstances at Muara Jambi District, from 12.562 population of beef cattle, there were remaining 4.622 beef cattle $(36,31 \%)$ were keeping by tenant within the share-beef cattle pattern and remaining 8.082 beef cattle $(63,97 \%)$ were kept by farmers owner (PSKS, 2011).

Various pattern of share-beef cattle that developed in Jambi Province particularly in beef cattle breeding were share-beef cattle based on share income and share-beef cattle based on inkind (share-beef cattle in the form of livestock such as share-beef cattle cow revolving system or share-beef cattle calf revolving system). In the share-beef cattle based on income share, the rate of share determined by mutual agreement between the owner of capital (the owners of beef cattle) and the tenant farmer. The rate of income share that received by the tenant usually fifty percent from the profit and fifty percent paid to the owner of the capital. The share-beef cattle based share in-kind is a modification from "gaduhan sapi Grati", which is currently used by government programs within share-beef cattle revolving cow or calf system refer to (Decree of the Minister of Agriculture Number.146/Kpts/HK.050/2/1993). In this pattern of share-beef cattle, the tenant farmers must return the number of calves within five years.

Viewed from traditional theory of share tenancy, several agriculture economists argued that share-tenancy in the case of agricultural land had caused an inefficiency of resource allocation. Several types of research showed that the level of technical efficiency production from share-tenancy was low. In contrast, the available empirical evidence on the efficiency of land tenure contract (Otsuka and Hayami, 1988) found that the majority of studies did not find significant inefficiency of share-tenancy. Widodo (2016) argued, that relatively low technical efficiency production from sharetenancy, did not closely related to a traditional theory of share tenancy, but related to allocation time in off-farm activity instead. The strictly land tenure and the limited of allocation time at on-farm activity had negatively affected to the technical efficiency level.

Knoeber (2000) argued that all contracts in land tenancy and contract production of livestock were formed because the parties expect to benefit. As the producer of calves, both of beef cattle breeding operated by owner and tenant required a function at maximum efficiency to achieve the optimal production. Farrel (1957) revealed that technical efficiency was the ability to produce a given level of output with a minimum amount of input under certain technologies. To improve beef cattle breeding efficiency production was closely related to optimality allocation of several inputs production. Most studies show that the production inputs that have influenced the 
production of beef cattle farming such as the number of forages, feed supplements, number of veterinary services, allocation of family labour, etc. (Isyanto et al., 2013; Indrayani et al., 2012; Kalangi et al., 2014).

The availability of beef cattle farming resources in Muaro Jambi, such as land area at palm oil plantation with high carrying capacity and the potential of the agricultural labour force in the rural area, are the support key to improving beef cattle breeding production. Besides that, the existence of share-beef cattle at farmer community and the government support with Mapping and Distribution Beef Cattle within Share-beef cattle Program (Program Penyebaran dan Pendistribusian Ternak Sapi Melalui Gaduhan) can overcome the lack of capital investment at the smallholder beef cattle farming level.

The recent studies showed the ownership status of cattle positively correlate to the technical efficiency of beef cattle cowcalf and fattening farming (Isyanto et al., 2013; Indrayani et al., 2012; Kalangi et al., 2014). In the specific study of the technical efficiency of traditional beef cattle fattening farming (Pramusintho et al., 2015), identified that the large percentage rate received by tenant in share-beef cattle based on shareincome had a positive correlation on the level of technical efficiency. This study focuses to observe the technical efficiency and determine the factors that influence inefficiency of beef cattle breeding operated by owner and tenant. Furthermore, there was considerable interest in explaining the distribution of efficiency and identifying its determinants. The results of the research could help public policy and managerial decision making for the development of the small beef cattle cow-calf sector in Jambi Province.

\section{Material and Methods}

\section{Technical sampling}

A multistage cluster sampling method procedure involving purposive technique were used to select the area of this study (Singarimbun and Efendi, 1989; Subiyanto, 2000; Eriyanto 2007). Three sub-districts in Muaro Jambi (Kumpe Ulu, Sungai Gelam Jambi and Jambi Luar Kota) as the centre of beef cattle areas had been chosen in the first stage. In the second stages, one village of a district which has the highest population of beef cattle was purposively chosen for sample area. Finally, the area of this study was conducted in three villages: Sungai Gelam at Sungai Gelam sub-district; Pudak at Kumpe Ulu sub-district and Sei Duren at Jambi Luar Kota sub-district.

The sample population in this study consist of two sub-population, specifically beef cattle breeding operated by owner and operated by tenant. Further, since there is the absence of information about the presence of beef cattle breeding operated by tenant in selected villages, accordingly the snowball sampling technique used to collect data from respondents. Snowball sampling technique is a purposive sampling technique. The number of samples obtained by snowball technique based on the need and availability of data (Sukandarrumidi, 2012). Further, the number of unit sample in this study amounted 108, consist of 59 beef cattle breeding operated by owner and 49 operated by tenant. The unit sample was limited by the criteria: the number of keeping at least two beef cattle and the breed of the cattle is Bali.

\section{Data analysis}

Technical efficiency which applied in production function is the maximum attainable level of output for a given level of inputs and the range of alternative technologies available to the farmer. The stochastic efficiency frontier models proposed independently by Meeusen and Van den Broeck (1977) and extended by Jondrow et al. (1982) was used in analysed the data and allowed for the estimation of individual firm efficiency level with both time variations and cross-sectional data. The general form of the stochastic efficiency frontier production function followed by: $Y_{i}=$ $f\left(X_{i}, \beta\right) \exp \left(v_{i}-u_{i}\right) ; i=1,2 \ldots . n$

Where:

$Y_{i}=$ Output of $i^{\text {th }}$ firm;

$X_{i}=$ corresponding $(M \times Z)$ vector of inputs;

$\beta=$ vector of unknown parameter to be estimated.;

$v_{i}=$ Symmetric error component that

accounts for random effects and exogenous shock;

$\mathrm{u}_{\mathrm{i}}<\mathrm{O}=\mathrm{a}$ one-sided error component that measures technical inefficiency.

Estimation of inefficiency effect (uI) from statistical noise, (vi) is accomplished by 
estimating the mean of conditional distribution of ui given vi expressed as: ui $=\mu i+\sigma^{*}\left(f *(-\mu i)[1-F(\mu i)](2) e . \sigma^{*} . \sigma^{*}\right.$

Where:

- $\sigma^{*}=\left(\sigma^{2} v \sigma^{2} u\right) 1 / 2 \mu=\left(-\sigma^{2}\right.$ u eui $) \sigma^{2} \sigma^{2}$;

$\mathrm{f}^{\star}=$ standard density function, and

$\mathrm{F}=$ standard distribution function.

The formulation was solved by means of maximum likelihood estimation (MLE), which involved the estimation of population parameters such as the probability density for obtaining the actual sample observation with any other assumed values (estimations) of the population parameter Battese and Coelli (1995). Model specification the stochastic frontier analysis introduced by Batesse and Coelli (1995) were applied in this study to generate both of the stochastic frontier production and the inefficiency model of beef cattle breeding operated by owners and tenants.The model estimation of stochastic frontier production function of beef cattle breeding operated by owner formulated as follows:

$\mathrm{LnY}_{10 \mathrm{i}}=\alpha_{0}+\alpha_{1} n \mathrm{X}_{10}+\alpha_{2} n \mathrm{X}_{20}+\alpha_{3} n \mathrm{X}_{30}+$ $\alpha_{4} n X_{4 o}+a ̈_{o i}$

where:

$\mathrm{Y}_{1 \mathrm{ai}}=$ production of beef cattle breeding operated by owner- $i$ (kg/ST/year);

$\alpha_{0-4}=$ regression coefficient

$X_{10 i}=$ number of feed forage $(\mathrm{kg} / \mathrm{ST} /$ year $)$

$X_{20 i}=$ number of feed

additional(kg/ST/year)

$X_{30 i}=$ number of vitamin (dose/ST/year)

$X_{40 i}=$ spacious the cattle shed $\left(\mathrm{m}^{2} / \mathrm{ST}\right)$.

$\ddot{a}_{o i} \quad=$ composite error term $\left(v_{o i}-u_{o i}\right)$; $\left(u_{o i}\right.$ $=$ technical inefficiency effects in the model)

The model estimation of stochastic frontier production function of beef cattle breedingoperated by tenant formulated as follows:

$\operatorname{LnY}_{2 t i}=\beta_{0}+\beta_{1} n X_{1 t}+\beta_{2} n X_{2 t}+\beta_{3 n} X_{3 t}+$

$\beta_{4 n} X_{4 t+} \ddot{a ̈ t i}_{t}$

where:

$\mathrm{Y}_{2 \mathrm{ti}} \quad=$ production form beef cattle

breeding operated by tenant- $i(\mathrm{~kg} / \mathrm{ST} / \mathrm{year})$

$\beta_{0-4} \quad=$ regression coefficient;

$X_{1+i}=$ number of feed forages

(kg/ST/year);

$X_{2 t i}=$ number of feed additional

(kg/ST/year) ;

$X_{3 t i}=$ number of vitamins and drugs

(kg/ST/year) ;

$X_{4 i}=$ spaciousthe cattle shed $\left(\mathrm{m}^{2} / \mathrm{ST}\right)$. $\ddot{a}_{t i} \quad=$ composite error term $\left(\mathrm{v}_{\mathrm{ti}}-\mathrm{u}_{\mathrm{ti}}\right) ;\left(\mathrm{u}_{\mathrm{ti}}\right.$ $=$ technical inefficiency effects in the model)

The ui variable is the inefficiency effect, assumed to be independent and normally distributed $\mathrm{N}\left(\mathrm{u}_{i} \sigma^{2}\right)$ Batesse and Coelli (1995). Estimation inefficiency model of beef cattle breedingoperated by owner and tenant were definedas:

$u_{10 \mathrm{i}}=$

$\delta_{0}+\delta_{1} Z_{10 \mathrm{i}}+\delta_{2} Z_{20 \mathrm{i}}+\delta_{3} Z_{30 \mathrm{i}}+\delta_{4} Z_{40 \mathrm{i}}+\delta_{5} Z_{50 \mathrm{i}}+\delta_{6} Z_{6 o \mathrm{o}}+\delta$ $7 \mathrm{Z}_{7 \mathrm{oi}}+e$

$u_{2 t i}=\gamma_{0}+\gamma_{1} Z_{1+i}+\gamma_{2} Z_{2 t i}+\gamma_{3} Z_{3 t i}+\gamma_{4} Z_{4 t i}+\gamma_{5} Z_{5 t i}+$ $\gamma_{6} Z_{6 t i}+\gamma_{7} Z_{7 t i}+\gamma_{8} Z_{8 t i}+\gamma_{9} Z_{9 t i}+e$

where:

$\mathrm{u}_{1 \mathrm{oi}}=$ inefficiency effect of the-i beef cattle breedingoperated by owner

$\mathrm{u}_{2 \mathrm{ti}} \quad=$ inefficiency effect of the-i beef

cattle breedingoperated by tenant

$Z_{1 \mathrm{oi}}, Z_{1 \mathrm{ti}}=$ number of allocation of family labour (HOK/ST/year)

$Z_{2 \mathrm{oi},} Z_{2 \mathrm{ti}} \quad=$ number of cow $(\mathrm{ST})$

$Z_{30 i}, Z_{3 \mathrm{ti}}, \quad=$ farmer age (year)

$Z_{4 \mathrm{oi}}, Z_{4 \mathrm{ti}} \quad=$ farmer education (year)

$Z_{50 i}, Z_{5 \mathrm{ti}} \quad=$ farmer experience (year)

$Z_{6 o i}, Z_{6 \mathrm{ti}}, \quad=$ dummy of cow-age, $=1$ if the average of cow age bettwen 18-60 month; $0=$ if

average of cow age $>60$ month

$Z_{7 \text { oi }} Z_{7 \mathrm{ti}}=$ dummy of $\mathrm{Al}$, = 1 if use artificial insemination ( $\mathrm{Al}) ; 0=$ if use natural breeding

$Z_{8 \mathrm{ti}} \quad=$ dummy pattern of share-beef cattle, = 1 if share-beef cattle based onshare income $(50: 50) ; 0=$ if otherwise

$Z_{9 \mathrm{ti}} \quad=$ dummy pattern of share-beef cattle based in kind, $1=$ if share-beef cattle cow revolving; $0=$ if otherwise

$$
\begin{array}{ll}
e & =\text { error term } \\
\delta_{\circ}, \bigvee_{0} & =\text { intercept } \\
\delta_{1}-\delta_{7} ; \bigvee_{1}-\gamma_{9} & =\text { parameter to be estimated }
\end{array}
$$

Variables in production function model. The specification of production function requires the definition of two type of variables: the output of beef cattle breeding (production) and the inputs employed in the production process. Production of the beef cattle cow-calf farm was the number of calves produced within a year. To calculation of output in physical quantities $(\mathrm{kg})$, we used to the selling value approach within one year (rupiah), then divided by the average price per $\mathrm{kg}$ of live weight (Rp/kg live weight). 
The inputs employed of beef cattle breeding production are represented by three variable factors of production (i.e. the number of forages, the number of feeds addition, the number of vitamins), and a fixed factor of production i.e. spacious of the cattle shed. With semi-intensive and communal rearing system, the inputs of production are given jointly for all of beef cattle have kept. In fact, the number of input production needs by the cattle, varies based on the age of cattle, thus in our study the measurement of all inputs of production, converted in animal unit or satuan ternak (ST). Conversion to satuan ternak (ST) was Refer to Direktorat Bina Usaha dan Pengolahan Hasil peternakan (1985), with defined that the cattle with age $<12$ month $=0.25 \mathrm{ST}$; the cattle with age $12-24$ month $=0.5 \mathrm{ST}$; and the cattle with age $>24$ months $=1 \mathrm{ST}$.

Therefore, the description of the all variables input of production in stochastic production function model as follow: a) the number of forages variable is the amount of forages (grass) given as fodder within one year divided by the number of beef cattle kept,in unit $\mathrm{kg} / \mathrm{ST} ; \mathrm{b})$ the number of feed addition variable is the amount of rice bran given as fodder within one year divided by the number of beef cattle kept, in unit $\mathrm{kg} / \mathrm{ST}$; c) the number of vitamin variable is the number of vitamins in the form of injected that given by the veterinarian within one year in unit dose/ST; and,d) spacious of the cattle shed in unit $\mathrm{m}^{2} / \mathrm{ST}$.

Variable in the inefficiency effect model. Variables hypothesised as influencing beef cattle breeding inefficiency are group into management capacity and environmental variables. Management capacity includes personal aspects (the farmer age, the farmer education, and farming experience). Definition of variables associated with the personal aspects are as follows: farmer age variable was specified inyear, farmer education was the length of time taking the level of formal education, specified inyears and farmer's experience was defined as the number of active years in the beef cattle breeding, specified inyear.

In this study, two variables use to reflect the decision in the farming management are: the allocation of family labour and the number of cows. The description of the allocation of family labour variable is the amount of working time from family labour, which used to manage beef cattle breeding within one year. The calculate of a number of working time, it's converted to an equivalent of man days (hari orang kerja /HOK), where the man days equal to 8 hours of work in a day (Soekartawi 2002); thus, for a female labour $=0.8 \mathrm{HOK}$ and a child labour $<15$ years old $=0.5 \mathrm{HOK}$. Futhermore, the description of the number of cows variable is a number of cow that keeping at beef cattle breeding, specified in unit ST.

Artificial insemination (Al) as a part of technology in the reproduction of beef cattle breeding, thus technological conditions are representing by the application Al.It is assumed that beef cattle breeding which using Al make a better to improve the cow's reproduction efficiency. Application of $\mathrm{Al}$ is a dummy variable; which $=1$ if the currently uses applies $\mathrm{Al}$, and $=0$ (zero) if use natural breed.

The variable that reflection reproduction efficiency of cow or reproduction performance at the beef cattle breedingis the cow age. Refers to Salisbury and Van Demark (1985), cow fertility increases up to 36 months old and flattens to 60 months old, then gradually decreases. These are reasonable that the cow age assumed as the proxy variable for the factor that influences the efficiency reproduction of cows,which finally influence the inefficiency of beef cattle breedingproduction. Thus the cow age is a dummy variable, $=1$ if the beef cattle breedingcurrently uses productive cows (average of the cow age between 1860 month) and $=0$ (zero) if use nonproductive cow (the average of the cow age $>60$ months).

Dummy the pattern of share-beef cattle base on share income (50:50)and share-beef cattle based in kind. We assume the pattern of share-beef cattle is part of the business environment that have to affect to the inefficiencies, especially has influence the decision in farming management of beef cattle breeding operated by tenant. The occurrence of the share-beef cattle due to the power interplay of demand and supply of production factors owned by the farmers and the owners of capital (Scheltema, 1985). Small beef cattle cow-calf farmers have limited capital, but on the other hand, they have the potential supply of family labour. Hence, the limited of capital, influence the 
farmer production decision, especially in decide the number of cows would be keeping and the allocation of family labour.

To analysed the pattern of share-beef cattle has an effect on the inefficiency, then the variable pattern of share-beef cattle is used as the dummy variable in the inefficiency model. There are three pattern of share-beef cattle in beef cattle breeding business in Muaro Jambi Regency, that are: share-beef cattle based on share income (50:50), share-beef cattle based in-kind (share-cow revolving system and share calf revolving system). The variables share-beef cattlebased in-kind (share-calf revolving system)use as the control variable, thus dummy variable share-beef cattle based on share income $(50: 50)=1$, if the share-beef cattle is based on share income (50:50); = 0 if otherwise. Likewise, the dummy variable share-beef cattle based in-kind; $=1$ if the share-cowrevolving system; $=0$ if otherwise.

\section{Result and Discussion}

\section{Description of variable}

The variables that used to estimate in frontier stochastic production function and inefficiency model (presented Table 1), showed that there were no significant differences in the average of the farmer age, farmer education and experience between farmer-owner and tenant. The average number of cows at the beef cattle breeding operated by tenant were significantly higher than operated by owner. The same result showed that the average number of forage intake, additional feed and allocation of family labour were higher in beef cattle breeding operated by tenant than operate by owner. However, there were no significant differences in the number of vitamin intake and spacious of the cattle shed.

In Table 2, figured that $47.46 \%$ of beef cattle breeding operated by owner using nonproductive cow (cow age > 60 months). In the other side, about $69.39 \%$ of beef cattle breeding operated by tenant, using cows at the range age 18-60 month or (productive cow). Related the breeding the cows, the proportion of applied Artificial Insemination $(\mathrm{Al})$ at beef cattle breeding operated by owner was higher than beef cattle breeding operated by tenant. It indicated that at $62,71 \%$ of beef cattle breeding operated by owner used Al to breed cross the cow, the others used natural breeding (bull). In the other side, $61.22 \%$ of beef cattle breeding operated by tenant using Al to breed cross the cow, the others used natural breeding.

\section{Production of beef cattle breeding}

Our study had found that the average production of beef cattle breeding operated by the owner was $87,94 \mathrm{~kg} / \mathrm{ST} /$ year and operated by the tenant was 119,70 $\mathrm{kg} / \mathrm{ST} /$ year (Table 1). The result of t-test for equality of means suggested that the means of production was different (significant at $\alpha$ $=95 \%$ ), which the average production from beef cattle breeding operated by the tenant was higher than operated by owner. Furthermore, to determine the factors that correlated to the efficiency production both of beef cattle farming operate by owner and tenant, we use the method of the stochastic frontier production function.

\section{Estimation of the stochastic frontier production function \\ The results of the estimation} Stochastic Production Frontier of beef cattle breeding operate by owner (Tabel 3 Col. I and II) showed, the estimated coefficient of feed additional (rice bran) was 0,07 and significant at $\alpha=1 \%$ level. This result indicated that the additional of feed additional intake was the most important contributor to frontier production of beef cattle breeding operated by owner.

Other results showed the coefficient parameter of the variables number of vitamin and spacious of cattle shed had the negative sign. The estimated coefficients for the variables number of vitamin was $(-0.01)$. The negative coefficient of the number of vitamin is due to reason that at $47.46 \%$ of beef cattle breedingoperated by owner using nonproductive cow (age of cow > 60 months), thus more susceptible to disease and their fertility declines. Vitamin and drug requirements are not the same depending on the cow age and stage production of cow. The vitamin and drug intake is more than that of requirements cause the decreasing marginal productivity level.

The estimated coefficients for the variables spacious of beef cattle shed was ($0.188)$. The negative sign of spacious of the 
Buletin Peternakan Vol. 41 (4): 472-483, November 2017 Bulletin of Animal Science, DOI: 10.21059/buletinpeternak.v41i4.18427

Table 1. Description variables and t-test for equality of means

\begin{tabular}{|c|c|c|c|c|c|}
\hline \multirow[t]{2}{*}{ Group Statistics } & \multirow[b]{3}{*}{ Owner } & \multirow{3}{*}{$\begin{array}{r}\text { Mean } \\
87.94\end{array}$} & \multirow{3}{*}{$\begin{array}{r}\text { Std. Deviation } \\
15.68\end{array}$} & \multicolumn{2}{|c|}{$\begin{array}{l}\text { t-test for Equality of } \\
\text { Means }\end{array}$} \\
\hline & & & & \multicolumn{2}{|c|}{ Sig.(2-tailed) $\alpha=95 \%$} \\
\hline \multirow[t]{2}{*}{ Production (kg/St/year) } & & & & 0.00 & Sig. \\
\hline & Tenant & 119.69 & 28.37 & 0.00 & \\
\hline \multirow[t]{2}{*}{ Number of forages (kg/ST/year) } & Owner & 2924.07 & 1512.54 & 0.00 & Sig. \\
\hline & Tenant & 3799.84 & 1349.28 & 0.00 & \\
\hline \multirow[t]{2}{*}{$\begin{array}{l}\text { Number of feeds_addition } \\
\text { (kg/ST/year) }\end{array}$} & Owner & 64.18 & 53.31 & 0.00 & Sig. \\
\hline & Tenant & 165.80 & 82.33 & 0.00 & \\
\hline \multirow[t]{2}{*}{ Number of vitamins (dose/ST/year) } & Owner & 0.40 & 0.32 & 0.45 & Nsig. \\
\hline & Tenant & 0.47 & 0.67 & 0.48 & \\
\hline \multirow[t]{2}{*}{ Spacious of the cattle shed (m2/ST) } & Owner & 2.34 & 0.81 & 0.98 & Sig. \\
\hline & Tenant & 2.33 & 0.86 & 0.98 & \\
\hline \multirow[t]{2}{*}{$\begin{array}{l}\text { Allocation of family labour } \\
\text { (HOK/ST/year) }\end{array}$} & Owner & 62.45 & 26.62 & 0.00 & Sig. \\
\hline & Tenant & 87.45 & 21.25 & 0.00 & \\
\hline \multirow[t]{2}{*}{ Number of cows (ST) } & Owner & 1.39 & 0.49 & 0.00 & Sig. \\
\hline & Tenant & 1.90 & 0.68 & 0.00 & \\
\hline \multirow[t]{2}{*}{ Farmer age (years) } & Owner & 48.86 & 11.56 & 0.83 & Nsig. \\
\hline & Tenant & 48.45 & 7.31 & 0.82 & \\
\hline \multirow[t]{2}{*}{ Farmer education (years) } & Owner & 15.47 & 5.58 & 0.32 & Nsig. \\
\hline & Tenant & 14.53 & 3.91 & 0.31 & \\
\hline \multirow[t]{2}{*}{ Experience (years) } & Owner & 0.47 & 0.50 & 0.02 & Sig. \\
\hline & Tenant & 0.69 & 0.47 & 0.02 & \\
\hline
\end{tabular}

Table 2. Dummy variable and frequency distribution

\begin{tabular}{lcc}
\hline \hline \multirow{2}{*}{ Description } & \multicolumn{2}{c}{ Freq (\%) } \\
\cline { 2 - 3 } & $\begin{array}{c}\text { beef cattle breeding operate } \\
\text { by owner }\end{array}$ & $\begin{array}{c}\text { beef cattle breeding operate } \\
\text { by tenant }\end{array}$ \\
\hline The average of cow age at 18-60 month & 47.46 & 69.39 \\
The average of cow age $>$ 60 month & 52.54 & 30.61 \\
Use artificial insemination (Al) & 62.71 & 61.22 \\
Use natural breeding & 37.29 & 38.78 \\
\hline
\end{tabular}

beef cattle shed should be as a result of the larger cattle shed area than the number of beef cattle that are kept. The implication for this result, the increase in beef cattle shed area without increasing the number of beef cattle causes a decrease in the marginal productivity of beef cattle breeding operate by owner.

The results of the estimated production function of beef cattle breedingoperated by tenants (presented in Table 3 Col. III and IV) showed that the coefficients of the input variables the number of forages, the number of feeds addition (rice bran) and the number of vitamins conform to a priori expectation of positive signs. These results indicated that the all variable were the most important contributor to production of beef cattle breedingproduction operated by tenant.

The coefficient of variables number of forages, the number of feeds addition (rice bran) and the number of vitamins were positive and significant at $\alpha=1 \%$ and $\alpha=10 \%$ levels. These imply that increasing the number of forages, a number of feeds additional, and a number of vitamins by $1 \%$ lead to increase in output of beef cattle 
breedingoperate by tenant about $0.210 \%$; $0.166 \%$; and $0.007 \%$ respectively.

Determinants of inefficiency beef cattle breeding

The result from the determinants inefficiency of beef cattle breeding operated by owners and tenants in inefficiency model (Table 3) showed that the sigma square of maximum likelihood estimation was 56.40 and 29.94 respectively, and both of statistically significant at the $\alpha=1 \%$ level and indicated a goodness of fit and correctness of the specified distribution assumed for the composite error term. The estimated value of the parameter $(\mathrm{Y})$ both in stochastic frontier production (SFP) of beef cattle breeding operated by the owner and operated by the tenant were 0.99 ; both of significant at the $\alpha$ $=1 \%$ level. These results indicated that $99 \%$ variation of the production level was caused by differences in technical efficiency while $1 \%$ was caused by variables outside the control of farmer or measurement error. The generalised likelihood ratio test 50.00 and 42.40 were statistically significant at the $\alpha=$ $1 \%$ level, indicating the presence of a onesided error component.

Based on the results of analysis inefficiency in the Cobb-Douglas frontier model (Table 3), showed that: allocation of family labour, the number of the cows, farmer age, farmer education, dummy cow age and dummy $\mathrm{Al}$ are individually significant determinants of the inefficiency of beef cattle breeding operated by owner. The number of cows, farmer age, dummy cow age and dummy $\mathrm{Al}$, have a negative coefficient, while the allocation of family labour and farmer education have a positive coefficient. In other result showed that dummy $\mathrm{Al}$ and dummy the pattern of share-beef cattle based on share-income (50:50) were negatively correlation to inefficiency of beef cattle breeding operated by tenant.

The coefficient of the number of cows has a negative sign. The number of cows was the most important variables that could improve the efficiency (or decrease of inefficiency) of beef cattle breeding operated by owner. The number of cows had a strong correlation to the level of the output and can be counted as an index of scale efficiency effect (Trestini, 2006) and have a positive effect on efficiency. This result supported by Kumbhakar et al. (1991), argue that the large farms are more efficient (technically) than small and medium-sized farms.

The coefficient of farmer age has a negative sign, and statistically significant. The results indicate the inefficiency of beef cattle breeding which manage by older

Table 3. Stochastic Frontier Production estimate and inefficiency model of beef cattle breeding operated by owner and operated by tenant

\begin{tabular}{|c|c|c|c|c|}
\hline \multirow{3}{*}{ Description } & \multicolumn{2}{|c|}{ Operate by owner } & \multicolumn{2}{|c|}{ Operated by tenant } \\
\hline & 1 & II & III & IV \\
\hline & Coef. & t-ratio & Coef. & t-ratio \\
\hline \multicolumn{5}{|l|}{ Frontier Production } \\
\hline Constant & $4.93^{\star \star \star}$ & 25.72 & $2.63^{* \star \star}$ & 5.90 \\
\hline Ln(number of forages) & $-0.04 \mathrm{~ns}$ & -1.60 & $0.21^{* \star \star}$ & 3.18 \\
\hline Ln(number of feed addition) & $0.07^{\star \star *}$ & 6.78 & $0.16^{\star *}$ & 2.48 \\
\hline Ln(number of vitamins ) & $-0.01^{* *}$ & -2.33 & $0.00^{*}$ & 1.99 \\
\hline Ln(spacious of cattle shed) & $-0.18^{\star \star *}$ & -9.40 & $-0.04 \mathrm{~ns}$ & -0.54 \\
\hline \multicolumn{5}{|l|}{ Inefficiency Model } \\
\hline Constant & $0.16 *$ & 1.81 & $1.17 \mathrm{~ns}$ & 1.40 \\
\hline Ln(allocation family labour) & $0.07^{* *}$ & 2.11 & $-0.21 \mathrm{~ns}$ & -1.11 \\
\hline Ln(number of cows) & $-0.08 *$ & -1.81 & $0.41 \mathrm{~ns}$ & 1.62 \\
\hline Farmer Age & $-0.003^{\star *}$ & -2.37 & $0.00 \mathrm{~ns}$ & 0.06 \\
\hline Farmer Education & $0.02^{\star \star \star}$ & 3.43 & $-0.00 \mathrm{~ns}$ & -0.10 \\
\hline Farmer Experience & $0.00 \mathrm{~ns}$ & 0.28 & $0.01 \mathrm{~ns}$ & 0.44 \\
\hline dummy cow age & $-0.08^{\star \star}$ & -2.65 & $-0.19 n s$ & -1.37 \\
\hline dummy Al & $-0.11^{\star \star \star}$ & -4.05 & $-0.71^{\star * *}$ & -3.15 \\
\hline dummy profit share & & & $-0.51^{\star *}$ & -2.21 \\
\hline dummy cattle share & & & $-0.06 \mathrm{~ns}$ & -0.19 \\
\hline Sigma-square & $0.00^{* \star *}$ & 5.00 & $0.04^{\star * *}$ & 2.72 \\
\hline Gamma(y) & $0.99^{\star * *}$ & 11.20 & $0.99^{\star \star \star}$ & 21.22 \\
\hline Log likelihood function & 56.40 & & 29.94 & \\
\hline LR Test & 50.00 & & 42.40 & \\
\hline
\end{tabular}
$\mathrm{n}=49, \quad{ }^{*} \alpha=10 \%(1.688) ;{ }^{* *} \alpha=5 \%(2.028) ;{ }^{* * *} \alpha=1 \%(2.719)$ 
farmers have less inefficiency than of that the young farmers. This result nearly identical to the study of (Isyanto et al., 2013), showed that the farmer's age has a negative correlation to inefficiency of beef cattle breeding in West Java.

Related to the farmer education, the coefficient parameter of farmer education variable has a positive sign. This result suggests that the farmers who have the higher education will result in lower efficiency or increase inefficiency. The characteristics of small beef cattle farming are subsistence agriculture, and subsistence agriculture becomes their "way of life". Considering the characteristic subsistence, management was not mostly affected by formal education but experience (Widodo, 2008). The implication of the result was the increase of farmer age need to accompany by increase informal education, especially through training and counselling to increase the farmer's knowledge related how to improve the efficiency reproduction of cow.

The allocation of the family labour of the beef cattle cow-calf farmer operated by owner positively influences inefficiency. These results indicate that the addition of working time will increase the inefficiency. The raising system of beef cattle breeding is semi-intensive (cattle grazed during the day), therefore actually the activity in beef cattle breeding does not require much working time. With the average of farm size at 2.55 ST, the addition of the working time but not following to the number of cattle keeping or farm size will increase the inefficiency. The same suggestion with Ahmad and BravoUreta (1996) cit. Tresini (2006), considering the family characteristics of farms analysed, it could be indicating the presence of hidden unemployment. The addition of working time from family labour should be adjusted with the enhance in the number of cattle that are kept and vice versa the enhance in the number of cattle that are kept should be adjusted with the availability of family labour (family labour supply). The unbalance between labour supply and the number of beef cattle will lead to increased inefficiency.

In other side, the variable of allocation family labour in beef cattle breeding operated by tenant, did not statistically significant influence to inefficiency. The result indicates the allocation of family labour did not matter to inefficiency since they could proportionally choose the optimal number of cows which they're rented within share-cattle and lead the supply of family labour.

The parameter estimated of the variable dummy cow age has a negative sign and statistically significant. Indicate that the technical efficiency of beef cattle breeding which keeping with productive cows (cow's age 18-16 month), is higher than that of beef cattle breeding which keeping with the nonproductive cow (cow age > 60 months). Itano et al. (2014) had found that there significantly effect between the aged cow and weaning weight. The weaning weight will decrease as the cow age increase.

The parameter estimated of the variable dummy $\mathrm{Al}$ has a negative sign and statistically significant to inefficiency both of beef cattle breeding operated by owner and operate by tenant. These suggest the technical efficiency of beef cattle breeding which uses $\mathrm{Al}$ is higher than that of beef cattle breeding which uses natural breeding. The use of Al to breed the cow, not only systematically improving the birth weight of calf, but also can avoid the occurrence of inbreeding. This result supported by Siregar et al. (1997), argues that the artificial insemination (Al) is one of the most effective ways to increase productivity and improvement the quality of cattle's genetic in Indonesia.

The parameter estimated of the variable dummy share-beef cattle based on share income (50:50) had a negative sign and statistically significant to the inefficiency of the beef cattle breeding operated by tenant. It suggests the technical efficiency of beef cattle breeding with the share-beef cattle based on share income (50:50) is higher than that of share-cattlebased in inkind.

Under the share-beef cattle based inkind (share-cow revolving system or share calf revolving system) basically resembles a fixed-rent, where the farmer-tenant obtain results cows that remain fixed within a periodic time. Different with the share-beef cattle based onshare income, the farmerstenant earning in cash and the value determined by cattle sales. With received in cash, the farmer-tenant can get addition income which can be used to purchase more production inputs. This is one of the reasons causing the technical efficiency under sharebeef cattle pattern based on share-income 
Table 4. The estimation level and frequency distribution of technical efficiency

\begin{tabular}{|c|c|c|c|c|c|}
\hline \multirow{2}{*}{ Efficiency Level } & \multicolumn{3}{|c|}{ Operated by owner } & \multicolumn{2}{|c|}{ Operated bytenant } \\
\hline & (n) & Freq.(\%) & (n) & & Freq. (\%) \\
\hline $41-50$ & 0.00 & 0.00 & & 3.00 & 6.12 \\
\hline $51-60$ & 8.00 & 13.56 & & 4.00 & 8.16 \\
\hline $61-70$ & 15.00 & 25.42 & & 8.00 & 16.33 \\
\hline $71-80$ & 22.00 & 37.29 & & 9.00 & 18.37 \\
\hline $80-90$ & 12.00 & 20.34 & & 10.00 & 20.41 \\
\hline $90-99$ & 2.00 & 3.39 & & 15.00 & 30.61 \\
\hline Total & 59.00 & 100.00 & & 49.00 & 100.00 \\
\hline Average & 0.732 & & & 0.790 & \\
\hline Min & 0.500 & & & 0.440 & \\
\hline Max & 0.990 & & & 0.990 & \\
\hline
\end{tabular}

(50:50) is higher than share-beef cattle based in-kind (share-cow revolving system as well share-calf revolving system).

The empirical results revealed the fact that the type of share-beef cattle pattern, influences the level of technical efficiency of beef cattle breeding operated by tenant. It indicates that different forms share-beef cattle pattern were subjected to different levels of technical efficiency.

\section{Analysis of technical efficiency}

The frequency distributions of technical efficiency (TE) scores (Table 4), shows the beef cattle cow-calf operated by owner achieved on average 0.73 level of efficiency and 0.79 for beef cattle breeding operate by tenant. A t-test for equality of means suggested that the means of technical efficiency was different ( $p$-value $<0,05)$, it means the technical efficiency of beef cattle breeding operated by the tenant was statistically higher than operated by owner.

Based on the average of the level of technical efficiency production of beef cattle breeding operated by owner, indicates inefficiency gap of 0.21 to technical efficiency level 0.95 . This implies that about $21.80 \%$ higher production could be achieved from $87.94 \mathrm{~kg} / \mathrm{ST} / \mathrm{year}$ to maximum feasible output at $107.11 \mathrm{~kg} / \mathrm{ST} / \mathrm{year}$. In other result show that the average of technical efficiency production of beef cattle breeding operated by tenant was 0.79 , indicates inefficiency gap of 0.16 or about 16.00 percent below the frontier with maximum feasible output at $138.85 \mathrm{~kg} / \mathrm{ST} /$ year.

\section{Conclusions}

The study had found that the average production of beef cattle breedingoperated by the owner was $87,94 \mathrm{~kg} / \mathrm{ST} /$ year and operated by the tenant was 119,70 $\mathrm{kg} / \mathrm{ST} / \mathrm{year}$. The average technical efficiency of beef cattle breedingoperated by owner was at 0.73 otherwise operated by tenant was at 0.79 . The inefficiency ofbeef cattle breedingoperated by owner was negatively corresponding to : 1) the number of cows; 2) the farmer age; 3) the cow age's, and 4) the application of artificial insemination (IA), but positively corresponding to total allocation of family labour and the farmer education. The inefficiency of beef cattle breedingoperated by tenant was negatively influenced by the application of artificial insemination (AI). Thus, indicate the policy maker should focus on improvement of reproduction technology in breeding cattle. Specific conclusion of our study indicates that technical efficiency ofbeef cattle breedingwas not only affected by the status ownership of beef cattle but also by the pattern of share-beef cattle. Related to the pattern of share-beef cattle,indicate that the share-beefcattle based on shareincome(50:50) may improve the value of technical efficiency compared to the share-beef cattle basedon share inkind (share-cow revolving system and share-calf revolving system).

\section{References}

Battese, G. E. and T. J. Coelli. 1995. A model for technical inefficiency effects in a stochastic frontier production 
function for data panel. J. Empirical Economics. 20: 325-332.

BPS. 2014. Statistik Indonesia 2014. Badan Pusat Statistik, Jakarta.

Direktorat Bina Usaha Petani Ternak dan Pengolahan Hasil Peternakan. 1985. Usaha Peternakan, Perencanaan Usaha, Analisa dan Pengelolaan. Direktorat Jenderal Peternakan dan Kesehatan Hewan. Kementrian Pertanian, Jakarta.

Eriyanto, S. F. 2007. Riset Kebijakan. Metode Penelitian untuk Pascasarjana. IPB Press, Bogor.

Farrel, M. J. 1957. The measurement of productive efficiency. J. Royal Stat. Society.120: 253-290.

Hadi and Ilham. 2002. Problem dan prospek pengembangan usaha pembibitan sapi potong di Indonesia. Jurnal Litbang Pertanian 21: 148-157.

Indrayani, I., R. Nurmalina, and A. Fariyanti. 2012. Analisis efisiensi teknis usaha penggemukan sapi potong di Kabupaten Agam Provinsi Sumatera Barat. Jurnal Peternakan Indonesia 14: 286-296.

Isyanto, A. Y., M. I. Semaoen, N. Hanani, and Syafrial. 2013. Measurement of farm level efficiency of beef cattle fattening in West Java Province Indonesia. J. Economics Sustainable Development. 4: 100-104.

Jondrow, J., C. A. K. Lovell, I. S. Materov, and P. Schmidt. 1982. On the estimation of technical inefficiency in Frontier Stochastic Production Function model. J. Econometrics 19: 233-238.

Kalangi, L. S., Y. Syaukate, and A. Priyantini. 2014. Technical efficiency of beef cattle breeding business in east Java Province. Media Peternakan 37: 136142.

Knoeber, C. R. 2000. Land and livestock contracting in agriculture: A principalagent perspective. Encyclopaedia of Law and Economics, 5920. http://encyclo.findlaw.com/5920book.p df. Accessed 20 July 2016.

Kumbhakar, S., G. Soumendra, and J. T. McGuckin. 1991. A generalised Production Frontier Approach for estimating determinants of inefficiency in U.S. dairy farms. J. Business and Economic Statistics.9: 279-286.
Meeusen, W. and J. van den Broeck. 1977. Efficiency estimation from CobbDouglas productionfunctions with composed error. International Economic Review 18: 435-444.

Otsuka, K. and Y. Hayami. 1988. Theories of Share Tenancy: a critical survey. Economic Development and Cultural Change. University of Chicago Press.

Pramusintho, B. S. Hartono, H. D. Darwanto, and A. Suryantini. 2015. Technical efficiency of small beef cattle fattening production in Muaro Jambi District, Jambi Province Indonesia. J. Economics Sustainable Development 6: 53-58.

PSKS. 2011. Pendataan Sapi Potong, Sapi Perah dan Kerbau 2011. Direktorat Jenderal Peternakan dan Kesehatan Hewan. Badan Pusat Statistik, Jakarta.

Salisbury, G. W. and N. L. VanDemark. 1985. Fisiologi Reproduksi dan Inseminasi Buatan pada Sapi. Diterjemahkan oleh R. Djaunar $1^{\text {st }}$ edn. 1961. Gadjah Mada University Press, Yogyakarta.

Scheltema, A. M. P. A. 1985. Bagi Hasil di Hindia Belanda. Yayasan Obor Indonesia, Jakarta.

Simatupang, P., E. Jamal, and M. H. Togatorop. 1994. Sistem gaduhan sapi tradisional Bali: Faktor pendorong, penopang dan karakteristiknya. Pusat Sosial Ekomomi dan Kebijakan Pertanian. Forum Penelitian Agro Ekonomi 12: 50-55.

Singarimbun, M. and S. Efendi. 1989. Metode Penelitian Survey LP3ES, Jakarta.

Siregar, R. A., P. Situmorang, dan K. Dwiyanto. 1997. Pemanfaatan teknologi Inseminasi Buatan (IB) dalam usaha peningkatan produktifitas sapi potong di Indonesia. Presented in Seminar Nasional Veteriner. Balai Penelitian Ternak, Bogor.

Sodiq, A. and M. Budiono. 2012. Produktivitas sapi potong pada kelompok tani ternak di pedesaan. Jurnal Agripet 12: 28-33.

Subiyanto, I. 2000. Metodologi Penelitian (Manajemen Akuntasi), Edisi Ketiga, UPP AMP YKPN, Yogyakarta.

Sukandarrumidi. $2012 . \quad$ Research Methodology: Practical guidelines for 
beginner researchers. Gadjah Mada University Press, Yogyakarta.

Trestini, S. 2006. Technical efficiency of Italian beef cattle production under a heteroscedastic non-neutral production frontier approach. Center for International Food and Agricultural Policy University of Minnesota. Presented at the $10^{\text {th }}$ Joint Conference on Food, Agriculture and the Environment, Duluth, Minnesota, pp. 1-18.
Widiati, R. 2012. Financial feasibility of beef cattle breeding with various capital aid in rural area of Gunung Kidul District of Yogyakarta. Buletin Peternakan 36: 122-128.

Widodo, S. 2008. Manajemen usaha tani dan efisiensi produksi. In: Campur Sari Agro Ekonomi. Edisi pertama. Liberty, Yogyakarta, pp. 85-92.

Widodo, S. 2016. Kelembagaan dalam pembangunan pertanian. In: Dinamika Pembangunan Pertanian. Liberty, Yogyakarta, pp.160-170. 